\title{
HMGB1: A new marker for estimation of the postmortem interval
}

\author{
KIYOSHI KIKUCHI ${ }^{1,6^{*}}$, KO-ICHI KAWAHARA ${ }^{1 *}$, KAMAL KRISHNA BISWAS $^{1}$, TAKASHI ITO $^{1}$, \\ SALUNYA TANCHAROEN ${ }^{10}$, NAOTO SHIOMI ${ }^{7}$, YOSHIRO KODA $^{8}$, FUMIYO MATSUDA $^{4}$, YOKO MORIMOTO ${ }^{3}$, \\ YOKO OYAMA $^{1}$, KAZUNORI TAKENOUCHI ${ }^{1}$, NAOKI MIURA ${ }^{5}$, NOBORU ARIMURA ${ }^{1}$, YUKO NAWA ${ }^{1}$, \\ SHINICHIRO ARIMURA ${ }^{1}$, MENG XIAO JIE ${ }^{1}$, BINITA SHRESTHA ${ }^{1}$, MASAHIRO IWATA ${ }^{2}$, KENTARO MERA ${ }^{2}$, \\ HISAYO SAMESHIMA ${ }^{1}$, YOSHIKO OHNO ${ }^{1}$, RYUICHI MAENOSONO ${ }^{1}$, YUTAKA TAJIMA ${ }^{6}$, \\ HISAAKI UCHIKADO ${ }^{9}$, TERUKAZU KURAMOTO ${ }^{6}$, KENJI NAKAYAMA ${ }^{6}$, MINORU SHIGEMORI ${ }^{9}$, \\ YOSHIHIRO YOSHIDA ${ }^{4}$, TERUTO HASHIGUCHI $^{1}$ and IKURO MARUYAMA ${ }^{1}$ \\ ${ }^{1}$ Division of Laboratory and Vascular Medicine, Field of Cardiovascular and Respiratory Disorders, \\ Department of Advanced Therapeutics, and ${ }^{2}$ Department of Dermatology, Kagoshima University \\ Graduate School of Medical and Dental Sciences, Kagoshima 890-8520; ${ }^{3}$ Department of Periodontology, \\ Kagoshima University Graduate School of Medical and Dental Sciences, Kagoshima 890-8544; \\ ${ }^{4}$ Division of Physical Therapy, School of Health Sciences, Faculty of Medicine, Kagoshima University, \\ Kagoshima 890-8560; ${ }^{5}$ Veterinary Teaching Hospital and Laboratory of Veterinary Diagnostic Imaging, \\ Faculty of Agriculture, Kagoshima University, Kagoshima 890-0065; ${ }^{6}$ Department of Neurosurgery, \\ Omuta City General Hospital, Omuta 836-8567; ${ }^{7}$ Department of Emergency, Saiseikai Shiga Hospital, \\ Rittou 520-3046; Departments of ${ }^{8}$ Forensic Medicine and Human Genetics, and ${ }^{9}$ Neurosurgery, \\ Faculty of Medicine, Kurume University School of Medicine, Kurume 830-0011, Japan; ${ }^{10}$ Department of \\ Pharmacology, Faculty of Dentistry, Mahidol University, Bangkok 10400, Thailand
}

Received May 13, 2009; Accepted October 29, 2009

DOI: $10.3892 /$ etm_00000019

\begin{abstract}
Estimation of the postmortem interval (PMI) is one of the most important tasks in forensic medicine. Numerous methods have been proposed for the determination of the time since death by chemical means. High mobility group box-1 (HMGB1), a nonhistone DNA-binding protein is released by eukaryotic cells upon necrosis. Postmortem serum levels of HMGB1 of 90 male Wistar rats stored at 4,14 and $24^{\circ} \mathrm{C}$ since death were measured by enzyme-linked immunosorbent assay. The serum HMGB1 level showed a time-dependent increase up to seven days at $4^{\circ} \mathrm{C}$. At $14^{\circ} \mathrm{C}$, the HMGB1 level peaked at day 3 , decreased at day 4 , and then plateaued. At $24^{\circ} \mathrm{C}$, the HMGB1 level peaked at day 2 , decreased at day 3 , and then plateaued. Our findings suggest that HMGB1 is related to the $\mathrm{PMI}$ in rats.
\end{abstract}

Correspondence to: Dr Ikuro Maruyama, Division of Laboratory and Vascular Medicine, Field of Cardiovascular and Respiratory Disorders, Department of Advanced Therapeutics, Kagoshima University Graduate School of Medical and Dental Sciences, 8-35-1 Sakuragaoka, Kagoshima 890-8520, Japan

E-mail: rinken@m3.kufm.kagoshima-u.ac.jp

\section{${ }^{*}$ Contributed equally}

Key words: high mobility group box-1, postmortem interval, forensic medicine

\section{Introduction}

In recent years, research associated with forensic medicine has at times been regarded as insufficient and of poor quality, particularly when parameters such as journal impact factors and external findings are taken into account. Forensic medicine involves different tasks as compared with clinical medicine (1). Estimation of the postmortem interval (PMI) is one of the most important tasks in forensic medicine (2). In the last 60 years, numerous methods have been proposed for the determination of the time since death by chemical means (3). Previous contributions have reviewed the historical background of this discipline and important postmortem processes, and have discussed the scientific basis underlying attempts to determine the time interval since death (4). Biochemical markers that help to evaluate the time since death have been investigated. These include protein fractions, urea, creatinine, glucose, iron, potassium, calcium, enzymes, immunohistochemical detection of insulin in pancreatic $\beta$-cells, the myo-albumin fraction and the level of strontium-90 calcium analogs (2,5-13). Using medical techniques such as measurement of body temperature, analyzing the liver, or assessing rigor mortis, the time since death can be accurately measured only for the first two or three days after death (4). The number of studies estimating the PMI has a reverse correlation with its importance and value in practice (14). Therefore, research on estimating the PMI is most important. 


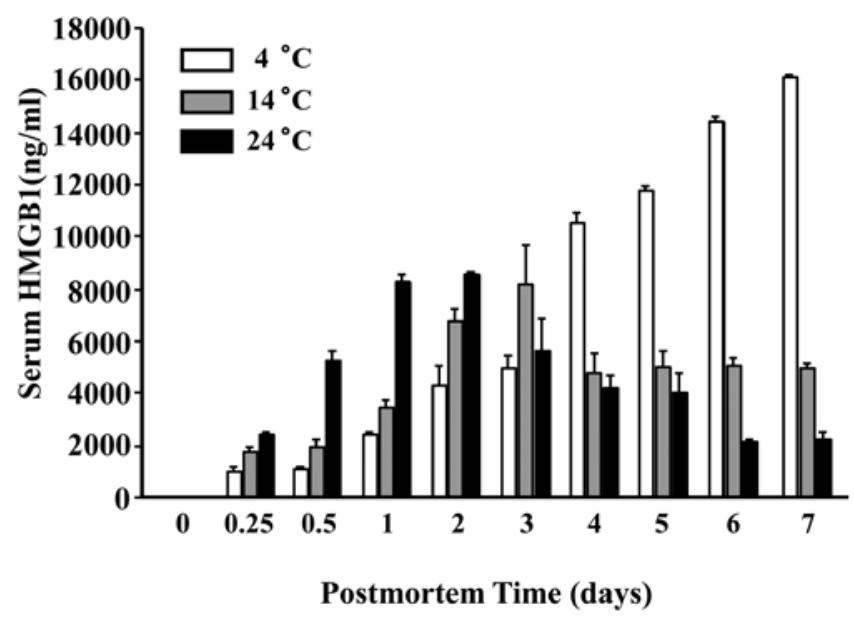

Figure 1. HMGB1 concentration in the serum of dead Wistar rats. Ninety male Wistar rats were sacrificed and stored at 4,14 and $24^{\circ} \mathrm{C}$. At $0,0.25,0.5$, 1, 2, 3, 4, 5, 6 and 7 days postmortem, blood samples were collected from each body. The serum HMGB1 concentration was measured by ELISA. At $24^{\circ} \mathrm{C}$, the serum HMGB1 level reached a peak on the second day with timedependent decrease in the following days whereas, at $14^{\circ} \mathrm{C}$, the level reached a peak on the third day and plateaued in the following days. The HMGB1 level showed a time-dependent increase at $4^{\circ} \mathrm{C}(\mathrm{n}=3$ for each group).

High mobility group box-1 (HMGB1) is primarily a nuclear protein present in many eukaryotic cells and has a highly conserved amino-acid sequence among species. HMGB1 appears to have two distinct functions in cellular systems. First, it acts as an intracellular regulator of transcription, having a crucial role in the maintenance of DNA function. Second, HMGB1 translocates to the outside of the nucleus in all eukaryotic cells upon necrosis, and is released from macrophages through activation by lipopolysaccharides (LPS), tumor necrosis factor (TNF)- $\alpha$, interleukin (IL)-1 and interferon (IFN)- $\gamma(15,16)$.

Studies demonstrating a role for HMGB1 in the PMI are lacking. Postmortem change induces necrosis, and necrotic cells release HMGB1 (16), so detection of serum HMGB1 exuded from corpus necrotic tissue may be related to PMI. In the present study, the postmortem change in serum HMGB1 in the bodies of dead rats at three environmental temperatures was detected. The aim of our study was to investigate the potential use of serum HMGB1 as an estimation of the PMI. Serum HMGB1 during the postmortem period was analyzed by enzyme-linked immunosorbent assay (ELISA).

\section{Materials and methods}

Animal protocol. Animal procedures were conducted with the approval of the Animal Care Committee of the Ethics Board of the Institute of Laboratory Animal Sciences of Kagoshima University (Kagoshima, Japan).

Ninety male Wistar rats (weight, 230-260 g; age, 8 weeks) were purchased from Japan SLC Inc. (Tokyo, Japan). They were maintained on a 12-h light/dark cycle with free access to food and water. Rats were anesthetized with chloral hydrate (400 mg/kg body weight, i.p.). They were sacrificed by cervical dislocation and stored at 4,14 and $24^{\circ} \mathrm{C}$. Room temperature was set at 4 or $24^{\circ} \mathrm{C}$, and a water bath (Thermominder SD, Taitec, Saitama, Japan) was set at $14^{\circ} \mathrm{C}$ for 7 days postmortem.
At $0,0.25,0.5,1,2,3,4,5,6$ and 7 days postmortem, blood was removed from each dead body.

Rat samples. Blood samples were collected from the heart and great vessels at autopsy. Samples were centrifuged immediately for $5 \mathrm{~min}$ at $5000 \mathrm{rpm}$. Serum was stored at $-80^{\circ} \mathrm{C}$ until analysis.

HMGB1 ELISA. The concentration of HMGB1 in serum was measured using an ELISA kit (Shino-Test Corp., Kanagawa, Japan).

Statistical analysis. Statistical analysis was carried out using the Student's t-test. $\mathrm{P}<0.05$ was considered significant.

\section{Results}

Postmortem change induces necrosis, and necrotic cells release HMGB1 (16). In the present study, the postmortem change in serum HMGB1 in the bodies of dead rats at three environmental temperatures was detected. At $24^{\circ} \mathrm{C}$, the serum HMGB1 level reached a peak on the second day with a timedependent decrease in the following days whereas, at $14^{\circ} \mathrm{C}$ the level reached a peak at day 3 with a plateau in the following days (Fig. 1). The HMGBI level showed a time-dependent increase at $4^{\circ} \mathrm{C}$. The standard deviation (SD) of HMGB1 levels was very small; reproducibility was probably high. The increase and decrease in HMGB1 levels at postmortem time was extemely large.

\section{Discussion}

Assessment of the PMI by HMGB1 measurement is a useful method. Serum samples of only $10 \mu \mathrm{l}$ are required, and organs do not need to be homogenized. HMGB1 levels can be obtained in just two days using ELISA. The HMGB1 level in a dead body can be used to estimate the PMI. Postmortem analysis of HMGB1 levels could provide an insight into the biochemical changes that occur after death, and could also present potential indicators for assessment of the PMI.

In live humans, the HMGB1 concentration in blood cells was very low in our preliminary data. In the experiment, blood samples were collected from live humans $(n=3)$. Samples were kept up to 7 days at $24^{\circ} \mathrm{C}$. The serum HMGB1 level was detected at $0,1,2,3,4,5,6$ and 7 days using ELISA. The HMGB1 level showed a time-dependent increase up to 7 days; the HMGB1 concentration in blood cells was very low (median, $6.24 \mathrm{ng} / \mathrm{ml}$ ).

The high level of HMGB1 in the bodies of dead rats may have been exuded from necrotic cells in the tissue of the heart and the great vessels, and not released only from blood cells.

HMGB1 has been identified to be a potent pro-inflammatory and cytotoxic cytokine (17). HMGB1 has a critical role in sepsis, cancer, disseminated intravascular coagulation, rheumatoid arthritis, cerebral infarction, myocardial infarction, periodontitis and xenotransplantation (18-27). The serum HMGB1 level is elevated in human patients with various diseases. In previous studies, serum HMGB1 levels were elevated in patients with myocardial ischemia (median, $159 \mathrm{ng} /$ $\mathrm{ml}$ ), cerebral ischemia (median, $218 \mathrm{ng} / \mathrm{ml}$ ), sepsis (median, $83.7 \mathrm{ng} / \mathrm{ml}$ ) and pancreatitis (median, $5.4 \mathrm{ng} / \mathrm{ml})(19,28,29)$. The 
maximal serum HMGB1 level is approximately $200 \mathrm{ng} / \mathrm{ml}$. The level of serum HMGB1 in dead rats is very high, suggesting that the cause of death may not influence postmortem serum HMGB1 levels when estimating the PMI.

Body temperature was not measured in the present study, but postmortem temperature has been reported in several publications (30-32).

In recent years, research associated with forensic medicine has sometimes been regarded as insufficient and of poor quality (1). Forensic medicine has been removed as an academic discipline from universities in some countries (33). Yet, forensic medicine has made advances. In addition to traditional invasive 'body-opening' autopsy of postmortem investigation in humans, virtual 'body non-opening' autopsy has been conducted using CT and MRI $(34,35)$. HMGB1 analysis may be a new method in forensic medicine. The data in the present study demonstrate that this technique may be a major advance in the determination of the time since death, providing reliable semi-quantitative biochemical markers from blood samples as opposed to estimates such as those based on direct measurement of temperature. HMGB1 is a new postmortem marker and could be a tool for the estimation of the PMI in the short- and long-term. Further investigations into the timing and physical factors that affect postmortem levels of HMGB1 in different tissues are essential, but detection of HMGB1 permits the development of techniques for the precise determination of the PMI. Upon further validation, this method could be used in combination with established methods to improve estimation of the PMI.

\section{Acknowledgements}

We thank N. Uto, T. Nagasato and T. Morizono for their excellent technical assistance.

\section{References}

1. Madea B, Saukko P and Musshoff F: Tasks of research in forensic medicine - different study types in clinical research and forensic medicine. Forensic Sci Int 165: 92-97, 2007.

2. Thaik-Oo M, Tanaka E, Tsuchiya T, et al: Estimation of postmortem interval from hypoxic inducible levels of vascular endothelial growth factor. J Forensic Sci 47: 186-189, 2002.

3. Madea B: Is there recent progress in the estimation of the postmortem interval by means of thanatochemistry? Forensic Sci Int 151: 139-149, 2005.

4. Amendt J, Krettek R and Zehner R: Forensic entomology. Naturwissenschaften 91: 51-65, 2004

5. Gallois-Montbrun FG, Barres DR and Durigon M: Postmortem interval estimation by biochemical determination in birds muscle. Forensic Sci Int 37: 189-192, 1988.

6. Gos T and Raszeja S: Postmortem activity of lactate and malate dehydrogenase in human liver in relation to time after death. Int J Legal Med 106: 25-29, 1993.

7. Kang S, Kassam N, Gauthier ML and O'Day DH: Post-mortem changes in calmodulin binding proteins in muscle and lung. Forensic Sci Int 131: 140-147, 2003.

8. Mittmeyer HJ: [Investigations to determine the time of death, late post mortem, by means of electrophoresis of inner organs (author's translation)]. Z Rechtsmed 84: 47-56, 1979.

9. Mittmeyer HJ: [Determination of the myo-albumin content. A possibility to determine the hour of death (author's translation)] Z Rechtsmed 84: 233-237, 1980.

10. Mittmeyer HJ and Strebel KH: [Experimental examinations on forensic determination of time of death by electrofocusing of soluble muscle protein (author's translation)]. Z Rechtsmed 85: 235-240, 1980.
11. Neis P, Hille R, Paschke M, et al: Strontium90 for determination of time since death. Forensic Sci Int 99: 47-51, 1999.

12. Sabucedo AJ and Furton KG: Estimation of postmortem interval using the protein marker cardiac Troponin I. Forensic Sci Int 134: 11-16, 2003.

13. Wehner F, Wehner HD, Schieffer MC and Subke J: Delimitation of the time of death by immunohistochemical detection of insulin in pancreatic beta-cells. Forensic Sci Int 105: 161-169, 1999.

14. Henssge $\mathrm{C}$ and Madea B: Estimation of the time since death. Forensic Sci Int 165: 182-184, 2007.

15. Ito T, Kawahara K, Nakamura T, et al: High-mobility group box 1 protein promotes development of microvascular thrombosis in rats. J Thromb Haemost 5: 109-116, 2007.

16. Scaffidi P, Misteli $T$ and Bianchi ME: Release of chromatin protein HMGB1 by necrotic cells triggers inflammation. Nature 418: 191-195, 2002.

17. Kawahara K, Tancharoen S, Hashiguchi T, et al: Inhibition of HMGB 1 by deep ocean water attenuates endotoxin-induced sepsis. Med Hypotheses 68: 1429-1430, 2007.

18. Dumitriu IE, Baruah P, Manfredi AA, Bianchi ME and RovereQuerini P: HMGB1: guiding immunity from within. Trends Immunol 26: 381-387, 2005.

19. Goldstein RS, Gallowitsch-Puerta M, Yang L, et al: Elevated high-mobility group box 1 levels in patients with cerebral and myocardial ischemia. Shock 25: 571-574, 2006.

20. Inoue K, Kawahara K, Biswas KK, et al: HMGB1 expression by activated vascular smooth muscle cells in advanced human atherosclerosis plaques. Cardiovasc Pathol 16: 136-143, 2007.

21. Kawahara K, Setoyama K, Kikuchi K, et al: HMGB1 release in co-cultures of porcine endothelial and human $\mathrm{T}$ cells. Xenotransplantation 14: 636-641, 2007.

22. Kikuchi K, Kawahara KI, Biswas KK, et al: Minocycline attenuates both OGD-induced HMGB1 release and HMGB1-induced cell death in ischemic neuronal injury in PC12 cells. Biochem Biophys Res Commun 385: 132-136, 2009.

23. Kikuchi K, Kawahara KI, Tancharoen S, et al: The free-radical scavenger edaravone rescues rats from cerebral infarction by attenuating the release of high-mobility group box-1 in neuronal cells. J Pharmacol Exp Ther 329: 865-874, 2009.

24. Lotze MT and Tracey KJ: High-mobility group box 1 protein (HMGB1): nuclear weapon in the immune arsenal. Nat Rev Immunol 5: 331-342, 2005.

25. Morimoto Y, Kawahara KI, Tancharoen S, et al: Tumor necrosis factor-alpha stimulates gingival epithelial cells to release high mobility-group box 1. J Periodontal Res 43: 76-83, 2008.

26. Taniguchi N, Kawahara K, Yone K, et al: High mobility group box chromosomal protein 1 plays a role in the pathogenesis of rheumatoid arthritis as a novel cytokine. Arthritis Rheum 48: 971-981, 2003.

27. Ulloa L and Messmer D: High-mobility group box 1 (HMGB1) protein: friend and foe. Cytokine Growth Factor Rev 17: 189-201, 2006.

28. Wang $\mathrm{H}$, Bloom O, Zhang M, et al: HMG-1 as a late mediator of endotoxin lethality in mice. Science 285: 248-251, 1999.

29. Yasuda T, Ueda T, Takeyama Y, et al: Significant increase of serum high-mobility group box chromosomal protein 1 levels in patients with severe acute pancreatitis. Pancreas 33: 359-363, 2006.

30. Henssge C: Concerning the paper by Mall et al, entitled 'Temperature-based death time estimation with only partially environment conditions' (Int J Legal Med (2005) 119: 185-194). Int J Legal Med 121: 82, 2007.

31. Henssge C, Althaus L, Bolt J, et al: Experiences with a compound method for estimating the time since death. I. Rectal temperature nomogram for time since death. Int J Legal Med 113: 303-319, 2000.

32. Mall G, Eckl M, Sinicina I, Peschel O and Hubig M: Temperature-based death time estimation with only partially known environmental conditions. Int J Legal Med 119: 185-194, 2005.

33. Vanezis P: Forensic medicine: past, present and future. Lancet 364: 8-9, 2004

34. Dirnhofer R, Jackowski C, Vock P, Potter K and Thali MJ: VIRTOPSY: minimally invasive, imaging-guided virtual autopsy. Radiographics 26: 1305-1333, 2006.

35. Hayakawa M, Yamamoto S, Motani H, Yajima D, Sato Y and Iwase $\mathrm{H}$ : Does imaging technology overcome problems of conventional postmortem examination? A trial of computed tomography imaging for postmortem examination. Int J Legal Med 120: 24-26, 2006. 